\title{
ANALISIS TANAH DISPERSIF TERHADAP FONDASI DRILLED SHAFT DENGAN METODE CASING
}

\author{
Chelvyn Christson Immanuel ${ }^{1}$, dan Chaidir Anwar Makarim² \\ ${ }^{1}$ Program Studi Sarjana Teknik Sipil, Universitas Tarumanagara, Jl. Letjen S. Parman No.1 Jakarta \\ Email: chelvyn20@gmail.com \\ ${ }^{2}$ Program Studi Sarjana Teknik Sipil, Universitas Tarumanagara, Jl. Letjen S. Parman No.1 Jakarta \\ Email: chaidir259@gamil.com
}

\begin{abstract}
ABSTRAK
Tanah dispersif merupakan tanah yang secara struktural tidak stabil dan mudah runtuh atau terurai bahkan pada kondisi air yang diam. Sementara itu fondasi drilled shaft merupakan fondasi yang dilakukan dengan pengecoran di tempat. Dengan kata lain, fondasi drilled shaft sangat dipengaruhi oleh kondisi tanah dan metode pelaksanaan yang dilakukan. Sehingga keberadaan tanah dispersif akan mempengaruhi fondasi drilled shaft jika dilakukan dengan metode pelaksanaan yang tidak sesuai. Kesalahan metode pelaksanaan terhadap kondisi tanah dapat menyebabkan dengan mudah fondasi drilled shaft mengalami kecacatan. Untuk mendeteksi kecacatan dilakukan pengujian daya dukung seperti pile driving analyzer test dan static load test, dan terhadap keutuhan tiang seperti pile integrity test. Pada skripsi ini akan dibahas mengenai pengaruh tanah dispersif terhadap daya dukung tanah dan keutuhan fondasi drilled shaft jika metode yang dilakukan dengan casing yang tidak menahan hingga lapisan tanah dispersif berdasarkan data-data penyelidikan tanah, pengujian dan laporan harian pada proyek hotel di Sumatra Barat. Selain itu juga akan dibahas mengenai pengaruhnya durasi konstruksi dari laporan harian terhadap kecacatan tiang, dan diberikan juga metode pelaksanaan yang sesuai untuk tanah dispersif.
\end{abstract}

Kata kunci: tanah dispersif, drilled shaft, daya dukung tanah, keutuhan tiang

\section{PENDAHULUAN}

\section{Latar belakang}

Fondasi drilled shaft merupakan salah satu jenis fondasi yang dicor di tempat sehingga konstruksi fondasi drilled shaft sangat dipengaruhi oleh kondisi tanah dan metode pelaksanaannya. Tanah dispersif merupakan tanah yang mudah terurai bahkan kondisi air yang diam dan juga merupakan salah satu kondisi tanah yang dapat menyebabkan kecacatan tiang. Penggunaan casing merupakan salah satu metode untuk menahan tanah runtuh selama pelaksanaan konstruksi namun panjang casing harus mencapai kedalaman lapisan tanah dispersif.

Seringkali untuk melakukan pengawasan terhadap pekerjaan yang telah dilakukan maka perlu dilakukan pengujian terhadap fondasi drilled shaft yang telah dibuat. Uji ini dilakukan dengan 2 metode yaitu metode statis dengan static loading test dan metode dinamik dengan pile dynamic analyzer (PDA) test dan pile integrity test. Static load test dan PDA test dilakukan untuk mengetahui daya dukung aksial tiang sedangkan pile integrity test dilakukan untuk mengetahui keutuhan tiang. Dari ketiga uji ini biasanya dilakukan analisis terhadap tiang untuk menentukan apakah tiang tersebut diterima atau ditolak.

Pada proyek hotel di Sumatra barat ini diduga memiliki tanah dispersif sepanjang tiang dilihat dari penyelidikkan tanah. Namun dalam pelaksanaanya hanya menggunakan casing sebagian yaitu panjang casing hanya 8 m. Melalui studi pada kasus tanah dispersif akan dilakukan pembacaan terhadap static load test dan PDA test untuk menunjukkan tanah dispersif mempunyai mempengaruhi daya dukung aksial tiang. Sedangkan pembacaan terhadap pile integrity test untuk mengetahui jenis-jenis kecacatan yang disebabkan oleh tanah dispersif yang berdampak langsung pada daya dukung aksial tiang tersebut.

\section{Tanah dispersif}

Menurut para ahli, tanah dispersif adalah tanah yang mudah terurai bahkan pada kondisi air yang diam. Pada tanah dispersif, mudah sekali terjadi erosi saat dilakukan penggalian terbuka. Pasir, kerikil dan beberapa lanau yang memiliki plastisitas rendah dapat digolongkan sebagai tanah dispersif karena non kohesi atau memiliki kohesi yang rendah. Namun juga ada beberapa clay (lempung) yang dapat digolongkan menjadi tanah dispersif walaupun memiliki kohesi yang tinggi. 
Lempung ini mudah terurai karena adanya kadar mineral sodium yang cukup tinggi. Sifat dari sodium yang dapat menyebabkan tanah lempung terurai jika adanya kontak dengan air. Saat kondisi kering (tanpa adanya air), sodium bereaksi dengan tanah lempung dan meningkatkan daya tarik menarik antar partikel dalam tanah tersebut. Namun saat kondisi basah, sodium melepaskan daya tarik menarik pada tanah lempung karena sodium lebih aktif untuk bereaksi dengan air.

\section{Konstruksi pada tanah caving atau squeezing}

Sebuah lubang dikatakan memiliki tanah caving apabila dinding tanah runtuh sebelum atau selama pengecoran dan dapat bercampur dengan beton. Peristiwa ini terjadi khususnya pada tanah pasir dibawah muka air tanah. Sedangkan squeezing mengacu pada dinding tanah yang menekan kedalam lubang baik selama atau setelah pengeboran dan seringkali terjadi pada tanah clay dan silt atau tanah dengan tingkat organik tinggi. Dengan kata lain tanah caving atau squeezing dapat disebabkan oleh tanah dispersif.

Kedua kondisi ini menyebabkan necking pada lubang (pengurangan lokal pada diameternya). Dua metode yang umum digunakan untuk mencegah terjadinya masalah ini yaitu dengan menggunakan casing atau menggunakan drilling fluid (slurry) dan kedua metode ini seringkali dipadukan untuk mengatasi masalah stabilitas pada tanah.

\section{Metode casing}

Metode casing dapat dilakukan dengan 2 cara yaitu: dengan permanent casing yaitu tidak menarik kembali casing yang telah tertanam dalam lubang dan temporary casing, yaitu dilakukan penarikan terhadap casing bersamaan dengan proses pengecoran. Casing digunakan untuk menahan lubang dinding tanah sehingga mencegah runtuhnya tanah selama pelaksanaan terutama selama pengecoran.

\section{Metode basah}

Metode basah biasanya dilakukan pada tanah yang memiliki muka air tanah yang tinggi dan pada lubang tanah tersebut tidak dapat dilakukan dewatering. Karena pada metode ini memiliki muka air tanah tinggi dan menggunakan slurry (campuran air dan bentonite) sehingga sering disebut metode basah. Penggunaan slurry dimaksudkan untuk mencegah rembesan air pada dinding lubang tanah yang dapat menyebabkan dinding tanah runtuh karena adanya tekanan hidrostatis air. Saat lubang diisi dengan slurry dan elevasi slurry di lubang lebih tinggi dibandingkan air tanah di dalam tanah sekitar lubang, terdapat gradien hidraulik diantara cairan di dalam lubang dan tanah sekitar yang akan mendorong slurry untuk merembes ke tanah sekitar.

\section{Static load test}

Cara yang paling sesuai untuk menentukan kapasitas tekan ultimit untuk fondasi dalam adalah dengan melakukan simulasi prototipe di lapangan pada fondasi yang telah jadi dan dibebani secara perlahan-lahan hingga mengalami kegagalan. Metode ini dikenal sebagai static load test. Terdapat metode-metode lain yang dapat menentukan kapasitas ultimit secara tidak langsung namun kurang akurat dibandingkan metode ini. Metode kerja dan perlengkapan untuk static load test telah distandardisasi pada ASTM D1143.

\section{Pile driving analyzer test (pda test)}

PDA test merupakan salah satu pengujian dinamik dengan menggunakan wave analysis method dan sering disebut re-strike test sesuai dengan sifat pengujiannya yang melakukan pemukulan ulang fondasi tiang yang diuji. Analisa data PDA dilakukan dengan prosedur case method, yang meliputi pengukuran data velocity (kecepatan) dan force (gaya) selama pelaksanaan pengujian (re-strike) dan perhitungan variabel dinamik secara real time untuk mendapatkan gambaran tentang daya dukung pondasi tiang tunggal.

\section{Pile integrity test}

Pile integrity test merupakan salah satu metode untuk menilai kondisi poros dan untuk mengetahui keutuhan / integritas luas dan volume fondasi tiang dengan menganalisa kemungkinan adanya retakan atau necking yang terjadi pada fondasi dalam. Biaya efektif dan tidak terlalu memakan waktu. Tes ini didasarkan pada teori perambatan gelombang. Saat berlangsungnya pile integrity test menghasilkan gelombang tekan yang bergerak ke bawah tumpukan pada kecepatan gelombang konstan (mirip dengan apa yang terjadi dalam pengujian high-strain dynamic test). Perubahan luas penampang seperti pengurangan diameter atau materi seperti kekosongan dalam beton menghasilkan refleksi gelombang.

\section{Daya dukung aksial fondasi drilled shaft}

Daya dukung aksial tiang tunggal suatu fondasi merupakan hasil penjumlahan daya dukung pada dua bagian fondasi yaitu daya dukung selimut dan daya dukung ujung dan dapat dinyatakan dengan persamaan berikut: 


$$
\begin{aligned}
& Q_{u}=Q_{s}+Q_{b} \\
& Q_{\text {all }}=\frac{Q_{u}}{S F}
\end{aligned}
$$

dengan: $Q_{s}=$ Daya dukung selimut $(\mathrm{kN}), Q_{b}=$ Daya dukung ujung $(\mathrm{kN}), Q_{u}=$ Daya dukung tanah ultimit $(\mathrm{kN})$, $Q_{\text {all }}=$ Daya dukung tanah ijin $(\mathrm{kN})$, dan $S F=$ Faktor keamanan

\section{Daya dukung selimut}

Daya dukung selimut merupakan daya dukung yang berasal dari gesekan atau tahanan sepanjang fondasi dan dapat dinyatakan dengan persamaan berikut:

$$
Q_{s}=\pi D \sum f_{i} L_{i}
$$

dengan: $D=$ Diameter drilled shaft $(\mathrm{m}), f_{i}=$ Tahanan selimut drilled shaft $\left(\mathrm{kN} / \mathrm{m}^{2}\right)$, dan $L_{i}=$ Tebal lapisan $(\mathrm{m})$

\section{Tahanan selimut di tanah kohesif}

Persamaan berikut merupakan metode $\alpha$ untuk evaluasi terhadap tahanan selimut drilled shaft di tanah kohesif pada kedalaman z:

$$
f_{s}=\alpha s_{u} \leq 260 \mathrm{kPa}
$$

dengan: $\alpha=$ Faktor adhesi empirikal terhadap kuat geser tak teralir, $s_{u}=$ Kuat geser tak teralir pada kedalaman $z$ $\left(\mathrm{kN} / \mathrm{m}^{2}\right)$

FHWA mengusulkan persamaan ini sebagai nilai dari $\alpha$ :

$$
\begin{aligned}
& \alpha=0.55-0.1\left(\frac{s_{u}}{p_{a}}-1.5\right) \quad ; 0.45 \leq \alpha \leq 0.55 \\
& \alpha=0 \text { pada kedalaman, } z \leq 1.5 m \text { dan } z \leq L-D
\end{aligned}
$$

dengan: $p_{a}=$ Tekanan atmosfer $=100 \mathrm{kPa}$

\section{Tahanan selimut di tanah non kohesif}

Persamaan berikut merupakan metode $\beta$ untuk evaluasi terhadap tahanan selimut drilled shaft di tanah non kohesif pada kedalaman z:

$$
f_{s}=\beta \sigma_{v}^{\prime} \leq 200 k P a
$$

dengan: $\beta=$ Faktor friksi, $\sigma_{v}^{\prime}=$ Tegangan efektif vertikal tanah pada kedalaman $z\left(\mathrm{kN} / \mathrm{m}^{2}\right)$

FHWA mengusulkan persamaan berikut sebagai nilai dari $\beta$ :

$$
\begin{array}{lll}
\text { untuk sand dengan } N_{60}<15, & \beta=\frac{N_{60}}{15}\left(1.5-0.245 z^{0.5}\right) & ; 0.25 \leq \beta \leq 1.20 \\
\text { untuk sand dengan } N_{60} \geq 15, & \beta=1.5-0.245 z^{0.5} & ; 0.25 \leq \beta \leq 1.80 \\
\text { untuk gravelly sand, } & \beta=2.0-0.15 z^{0.75} & ; 0.25 \leq \beta \leq 1.80 \\
\text { untuk gravel, } & \beta=3.4 e^{-0.085 z} & ; 0.25 \leq \beta \leq 3.0
\end{array}
$$

\section{Daya dukung ujung}

Daya dukung ujung merupakan daya dukung yang berasal dari tahanan ujung fondasi dan dapat dinyatakan dengan persamaan berikut:

$$
Q_{b}=q_{b} A_{b}
$$

dengan: $q_{b}=$ Tahanan ujung drilled shaft $\left(\mathrm{kN} / \mathrm{m}^{2}\right), A_{b}=$ Luas penampang drilled shaft $\left(\mathrm{m}^{2}\right)$

\section{Tahanan ujung di tanah kohesif}


Berdasarkan FHWA, persamaan berikut digunakan untuk menghitung tahanan ujung drilled shaft di tanah kohesif pada kedalaman $z$ :

$$
q_{b}=N^{*}{ }_{c} \bar{s}_{u}
$$

dengan: $N^{*}{ }_{c}=$ Faktor kapasitas, $\bar{s}_{u}=$ Kuat geser tak teralir antara ujung dan kedalaman $2 D$ di bawah ujung $\left(\mathrm{kN} / \mathrm{m}^{2}\right)$

\section{Tahanan ujung di tanah non kohesif}

Berdasarkan FHWA, persamaan berikut digunakan untuk menghitung tahanan ujung drilled shaft di tanah non kohesif pada kedalaman $z$ :

$$
q_{p}=57.5 \bar{N}_{60} \leq 2900 \mathrm{kPa}
$$

dengan: $\bar{N}_{60}=N_{s p t}$ rata-rata antara ujung dan kedalaman $2 D$ di bawah ujung

\section{Parameter tanah}

Perhitungan daya dukung tanah pada pondasi drilled shaft menggunakan beberapa korelasi parameter tanah berdasarkan hubungan empiris. Berikut adalah korelasi empiris baik dalam bentuk tabel, grafik dan persamaan yang digunakan untuk interpretasi hasil uji SPT:

1. Tanah dapat diklasifikasi dengan menggunakan USCS (Unified Soil Classification System) menurut sifatnya sebagai berikut. Kohesif: CH, CL, MH, ML, SC, GC dan non kohesif: GW, GP, GM, SW, SP, SM.

2. Berat jenis tanah: parameter yang digunakan pada analisis ini adalah $\gamma_{\text {sat }}$. Penentuan $\gamma_{\text {sat }}$ diambil berdasarkan hubungan klasifikasi tanah yang terdapat pada Tabel 1 sebagai berikut:

Tabel 1. Korelasi $\gamma_{\text {sat }}$ Terhadap Klasifikasi Tanah

(Sumber: Coduto, 2016)

\begin{tabular}{ccc}
\hline \multirow{2}{*}{ Soil Classification } & \multicolumn{2}{c}{ Typical Unit Weight, $\boldsymbol{r}_{\text {sat }}\left(\mathbf{k N} / \mathbf{m}^{\mathbf{3}}\right)$} \\
\cline { 2 - 3 } & Above Groundwater & Below Groundwater \\
\hline GP - Poorly graded & $17.5-20.5$ & $19.5-22.0$ \\
\hline GW - Well graded Gravel & $17.5-22.0$ & $19.5-23.5$ \\
\hline GM - Silty Gravel & $16.0-20.5$ & $19.5-22.0$ \\
\hline GC - Clayey Gravel & $16.0-20.5$ & $19.5-22.0$ \\
\hline SP - Poorly graded Sand & $15.0-19.5$ & $19.0-21.0$ \\
\hline SW - Well graded Sand & $15.0-21.0$ & $19.0-23.0$ \\
\hline SM - Silty Sand & $12.5-21.0$ & $17.5-22.0$ \\
\hline SC - Clayey Sand & $13.5-20.5$ & $17.5-21.0$ \\
\hline ML - Low plasticity Silt & $11.5-17.5$ & $12.5-20.5$ \\
\hline MH - High plasticity Silt & $11.5-17.5$ & $11.5-20.5$ \\
\hline CL - Low plasticity Clay & $12.5-17.5$ & $11.5-20.5$ \\
\hline CH - High plasticity Clay & $12.5-17.5$ & $11.0-19.5$ \\
\hline
\end{tabular}

3. Tahanan pada tanah kohesif biasanya hanya diambil berdasarkan nilai kohesinya oleh karena itu kuat geser $\left(s_{u}\right)$ pada tanah kohesif adalah sama dengan kohesinya. Nilai $s_{u}$ dapat diperoleh dari hubungan nilai $\underline{N}_{s p t}$ pada Gambar 1. 


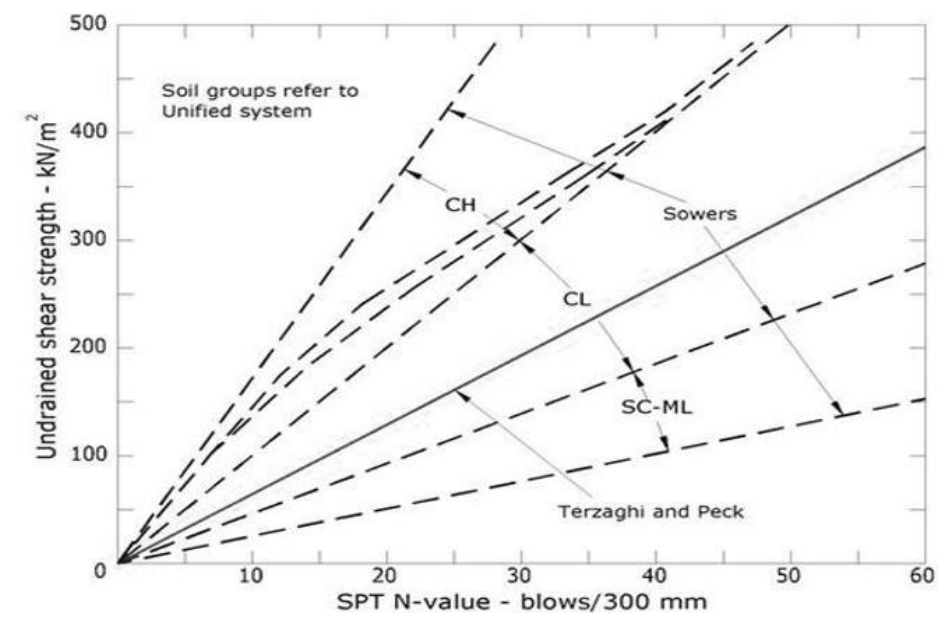

Gambar 1. Hubungan $N_{s p t}$ Terhadap $S_{u}$ pada Tanah Kohesif

(Sumber: Terzaghi dan Peck, 1967)

4. $N_{60}$ merupakan $N_{s p t}$ yang dikoreksi terhadap efisiensi energi pukulan pada berbagai jenis hammer. Koreksi empiris yang dianjurkan oleh Terzaghi dan Peck (1948) adalah sebagai berikut:

$\operatorname{untuk} N_{\text {spt }}>15 \quad N_{60}=15+\frac{1}{2}\left(N_{\text {spt }}-15\right)$

dengan: $N_{s p t}=N_{s p t}$ lapangan (untuk $N_{s p t} \leq 15$ tidak dikoreksi), $N_{60}=N_{s p t}$ koreksi hasil perhitungan empiris

\section{METODOLOGI PENELITIAN}

\section{Metode pengumpulan data}

Pengumpulan data skripsi ini menggunakan teknik dokumentasi yang merupakan salah satu metode pengumpulan data kualitatif dengan menganalisis dokumen-dokumen yang dibuat. Data yang dikumpulkan meliputi data dari proyek hotel di Sumatra Barat berupa laporan hasil penyelidikan tanah bore log, laporan harian pelaksanaan dan dokumen hasil pengujian lapangan seperti: PDA test, static load test dan pile integrity test.

\section{Metode analisis data}

Analisis dilakukan dengan program microsoft excel untuk membantu pengolahan data. Studi literatur diperlukan sebelum dilakukan analisis data seperti mencari dasar-dasar teori dan sumber data yang baik seperti dari buku referensi, jurnal penelitian, studi kasus, dan sebagainya untuk memperoleh rumus yang diperlukan untuk melakukan perhitungan daya dukung tekan, cara membaca hasil PIT dan metode pelaksaanaan pada fondasi drilled shaft

\section{ANALISIS DAN PEMBAHASAN}

\section{Perbandingan hasil daya dukung aksial}

Perbandingan hasil daya dukung aksial antara perhitungan manual dan hasil PDA test ditunjukkan pada Tabel 2. Hasil perbandingan menyatakan tiang BP 246 dan SP 76 dengan diameter $0.8 \mathrm{~m}$ memenuhi sedangkan BP 126 dengan diameter $1.2 \mathrm{~m}$ dari hasil PDA test lebih rendah dibandingkan perhitungan manual yaitu sekitar $70.8 \%$ sehingga memungkinkan terjadinya kegagalan.

Tabel 2. Perbandingan Daya Dukung Perhitungan Manual dan PDA Test

\begin{tabular}{ccccc}
\hline \multicolumn{2}{c}{ PDA Test } & D $(\mathbf{m})$ & Qu $(\mathbf{k N})$ & Qa $(\mathbf{k N})$ \\
\hline \multirow{3}{*}{ DB-1 } & Manual & 0.8 & 5964 & 1988 \\
\cline { 2 - 5 } & BP 246 & 0.8 & 5424 & 2411 \\
\cline { 2 - 5 } & SP 76 & 0.8 & 7196 & 3198 \\
\hline \multirow{2}{*}{ DB-2 } & Manual & 1.2 & 12629 & 4210 \\
\cline { 2 - 5 } & BP 126 & 1.2 & 6707 & 2981 \\
\hline
\end{tabular}


Perbandingan hasil daya dukung aksial antara perhitungan manual dan hasil static load test ditunjukkan pada Tabel 4.13. Berdasarkan hasil perbandingan untuk tiang no. BP 52 didapat bahwa hasil static load test lebih rendah dibandingkan perhitungan manual baik pada data tanah bore log DB-1 yaitu sekitar $47.7 \%$ maupun bore log DB-2 sekitar $44.3 \%$ sehingga sangat memungkinkan kegagalan.

Tabel 3 Perbandingan Daya Dukung Perhitungan Manual dan Static Load Test

\begin{tabular}{ccccc}
\hline \multicolumn{2}{c}{ Static Load Test } & D $(\mathbf{m})$ & Qu $(\mathbf{k N})$ & Qa $(\mathbf{k N})$ \\
\hline \multirow{2}{*}{ DB-1 } & Manual & 1.2 & 11097 & 3699 \\
\cline { 2 - 5 } & BP 52 & 1.2 & 3527 & 1763 \\
\hline \multirow{2}{*}{ DB-2 } & Manual & 1.2 & 11928 & 3976 \\
\cline { 2 - 5 } & BP 52 & 1.2 & 3527 & 1763 \\
\hline
\end{tabular}

\section{Hasil interpretasi pile integrity test}

Dari hasil PIT terhadap 90 tiang dengan diameter $1.2 \mathrm{~m}$, terdapat 24 tiang atau $\pm 26.7 \%$ yang dinyatakan memenuhi, karena memiliki nilai BTA $\geq 80 \%$, memiliki panjang sesuai dan mutu beton memenuhi karena cepat rambat gelombang $\geq 3700 \mathrm{~m} / \mathrm{s}$. Terdapat 34 tiang memiliki adanya perubahan impendasi dan mutu beton jelek ditunjukkan dengan cepat rambat gelombang $<3700 \mathrm{~m} / \mathrm{s}$. Terdapat 25 tiang yang memiliki panjang tiang yang tidak sesuai atau kurang dari asumsi panjang aktual. Terdapat 4 tiang yang tidak dapat diinterpretasikan dan terdapat 3 tiang yang mengalami necking dan masing-masing tiang ini memiliki BTA $<80 \%$.

\section{Analisis pengaruh tanah dispersif terhadap keutuhan tiang}

Menurunnya kapasitas tiang disebabkan oleh tanah dispersif yang mempunyai dampak terhadap keutuhan tiang. Hasil PIT menunjukkan bahwa terdapat 3 jenis pembacaan pada PIT yang mengindikasikan tiang mengalami kecacatan dan 3 jenis kecacatan tiang sebagai berikut:

1. Kualitas mutu beton yang tidak baik disebabkan oleh tanah yang runtuh sebelum atau selama pengecoran dan bercampur dengan beton.

2. Panjang tiang yang kurang disebabkan oleh tanah mengendap dan tidak bercampur dengan beton saat pengecoran. Tinggi endapan ini meliputi selisih antara panjang tiang rencana dan panjang tiang aktual.

3. Pengecilan diameter tiang atau necking disebabkan oleh tanah runtuh selama atau setelah pengecoran dan menekan beton sehingga diameter berkurang.

\section{Analisis pengaruh kerusakan tiang terhadap daya dukung}

Pada pengujian PIT, tiang BP 52 ini menunjukkan bahwa memiliki panjang tiang yang kurang. Hal ini menunjukkan bahwa kemungkinan besar terdapat endapan pada ujung tiang. Hasil perbandingan daya dukung antara manual dan static load test menunjukkan bahwa tiang ini tidak memenuhi kapasitas rencana bahkan < 50\% dari kapasitas yang diharapkan. Pada Gambar 2. menunjukkan kurva beban terhadap waktu dan penurunan tiang uji BP 52. Terlihat bahwa tiang mengalami penurunan ekstrim saat dibebankan lebih dari 300 ton.

Hal ini mungkin disebabkan oleh tanah runtuh dan mengendap sehingga ujung tiang pada endapan. Sedangkan pada hasil perhitungan daya dukung diketahui daya dukung tiang terutama diberikan oleh ujung tiang karena memiliki tanah dasar dengan nilai $N_{s p t}$ yang tinggi. Oleh karena itu panjang tiang sangat mempengaruhi daya dukung tiang terutama pada tiang yang bergantung pada daya dukung ujungnya. Dengan kata lain, tiang dengan panjang yang kurang harus ditolak.

Sedangkan daya dukung tiang pada kecacatan terjadi akibat mutu beton yang kurang baik ataupun necking lebih bergantung kapasitas tiang itu sendiri dibandingkan daya dukung tanah. Karena selama besar beban yang diberikan tidak membuat tiang tersebut patah seharusnya tegangan beban dapat ditransfer dan ditahan oleh daya dukung tanah. Namun jika tiang tersebut patah, hal lain yang mempengaruhi adalah letak kerusakan tersebut karena panjang tiang untuk menerima tahanan selimut pun berkurang apalagi tahanan ujung bisa mencapai nol. 


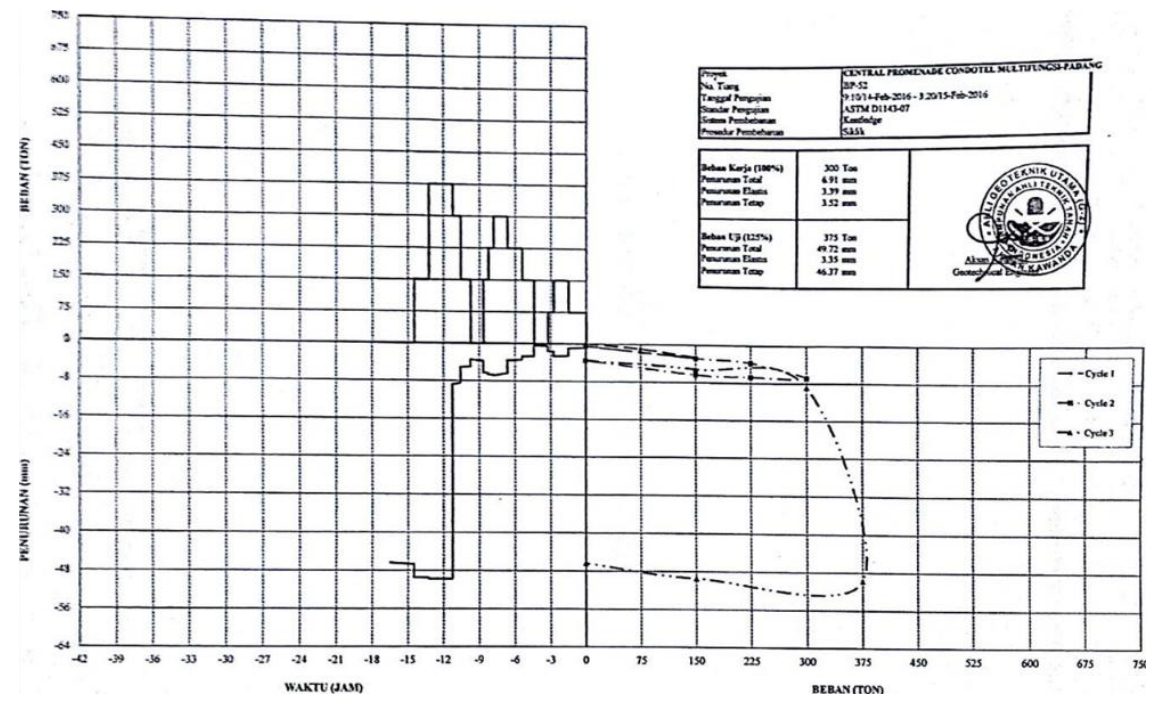

Gambar 2. Kurva Beban - Waktu - Penurunan Tiang No. BP 52

(Sumber: Dokumen Static Load Test Proyek Hotel di Sumatra Barat)

\section{Analisis pengaruh durasi konstruksi terhadap kerusakan tiang}

Laporan harian menunjukkan lamanya waktu pengeboran, pemasangan tulangan, pemasangan tremie, waktu tunggu datangnya beton dan lamanya pengecoran. Terdapat beberapa tiang yang tidak memiliki laporan harian seperti BP 35, BP 56, BP 58, dan BP 124 sehingga tidak dimasukkan dalam analisis ini.

Agar total durasi sama dengan durasi dari proses pengeboran hingga selesai pengecoran maka waktu tunggu tetap diperhitungkan seperti waktu tunggu beton. Waktu tunggu lain yaitu waktu tunggu untuk pemasangan tulangan yang mana diasumsikan merupakan durasi pengeboran. Pada Tabel 4. menunjukkan perbandingan jumlah tiang terhadap durasi pengeboran, pemasangan tulangan, pemasangan tremie hingga menunggu datangnya beton, lamanya pengecoran dan total durasi.

Tabel 4. Perbandingan Jumlah Tiang Terhadap Durasi Konstruksi

\begin{tabular}{|c|c|c|c|c|c|c|c|c|c|c|c|c|c|c|c|c|}
\hline \multirow[t]{2}{*}{ No. } & \multirow{2}{*}{ Tiang } & \multicolumn{3}{|c|}{$\begin{array}{c}\text { Durasi Pengeboran } \\
\text { (Hari) }\end{array}$} & \multicolumn{3}{|c|}{$\begin{array}{c}\text { Durasi Penulangan } \\
\text { (Hari) }\end{array}$} & \multicolumn{3}{|c|}{$\begin{array}{c}\text { Durasi Tremie + } \\
\text { Tunggu Beton (Hari) }\end{array}$} & \multicolumn{3}{|c|}{$\begin{array}{c}\text { Durasi Pengecoran } \\
\text { (Hari) }\end{array}$} & \multicolumn{3}{|c|}{ Total Durasi (Hari) } \\
\hline & & $<0.25$ & $0.25-0.5$ & $>0.5$ & $<0.25$ & $0.25-0.5$ & $>0.5$ & $<0.25$ & $0.25-0.5$ & $>0.5$ & $<0.25$ & $0.25-0.5$ & $>0.5$ & $<0.25$ & $0.25-0.5$ & $>0.5$ \\
\hline & \multirow{2}{*}{ Tiang Bagus } & & 0 & 2 & & 0 & 0 & & 2 & 4 & & 0 & & 11 & 6 & 6 \\
\hline & & 91 & $0 \%$ & $9 \%$ & $100 \%$ & $0 \%$ & $0 \%$ & $74 c$ & $9 \%$ & $17 \%$ & $100 \%$ & $0 \%$ & $0 \%$ & & $26 \%$ & $26 \%$ \\
\hline & \multirow{2}{*}{$\begin{array}{c}\text { Mutu Beton Tidak } \\
\text { Bagus }\end{array}$} & 30 & 0 & 2 & & 0 & 0 & & 4 & 2 & 3 & 0 & & 15 & 13 & 4 \\
\hline & & $94 \%$ & $0 \%$ & $6 \%$ & $100 \%$ & $0 \%$ & $0 \%$ & $81 \%$ & $13 \%$ & $6 \%$ & $100 \%$ & $0 \%$ & $0 \%$ & $47 \%$ & $41 \%$ & $13 \%$ \\
\hline & \multirow{2}{*}{$\begin{array}{l}\text { Panjang Tiang } \\
\text { Kurang }\end{array}$} & & 0 & 3 & & 0 & 0 & & 3 & 8 & & & & & & 11 \\
\hline & & $88 \%$ & $0 \%$ & $13 \%$ & $100 \%$ & $0 \%$ & $0 \%$ & $54 \%$ & $13 \%$ & $33 \%$ & $100 \%$ & $0 \%$ & $0 \%$ & $21 \%$ & $33 \%$ & $46 \%$ \\
\hline & \multirow{2}{*}{ Necking } & 3 & 0 & 0 & 3 & 0 & 0 & 2 & 1 & 0 & 3 & 0 & 0 & 1 & 2 & 0 \\
\hline & & $100 \%$ & $0 \%$ & $0 \%$ & $100 \%$ & $0 \%$ & $0 \%$ & $67 \%$ & $33 \%$ & $0 \%$ & $100 \%$ & $0 \%$ & $0 \%$ & $33 \%$ & $67 \%$ & $0 \%$ \\
\hline
\end{tabular}

Dari hasil perbandingan diketahui durasi pemasangan tremie + tunggu beton adalah hal utama yang menyebab runtuhnya tanah karena pada durasi $>0.5$ hari lebih besar dibanding durasi jenis konstruksi lainnya. Oleh karena itu durasi konstruksi akan diperhitungkan hanya berdasakan durasi pemasangan tremie + tunggu beton yang akan dibandingkan terhadap keutuhan tiang.

Pada Gambar 3. menunjukkan cepat rambat akan mengalami penurunan ketika durasi konstruksi semakin lama. Pada Gambar 4. menunjukkan grafik tingginya endapan terhadap durasi konstruksi pada tiang dengan panjang tiang kurang. Pada gambar ini menunjukkan 2 garis tren yang berarti kemungkinan terdapat 2 zona tanah, garis tren pertama pada tanah yang mengalami runtuh banyak terhadap waktu dan garis tren kedua pada tanah yang mengalami runtuh sedikit terhadap waktu. Masing-masing garis tren menunjukkan semakin lama durasi konstruksi maka semakin banyak tanah yang runtuh dan menjadi endapan. 


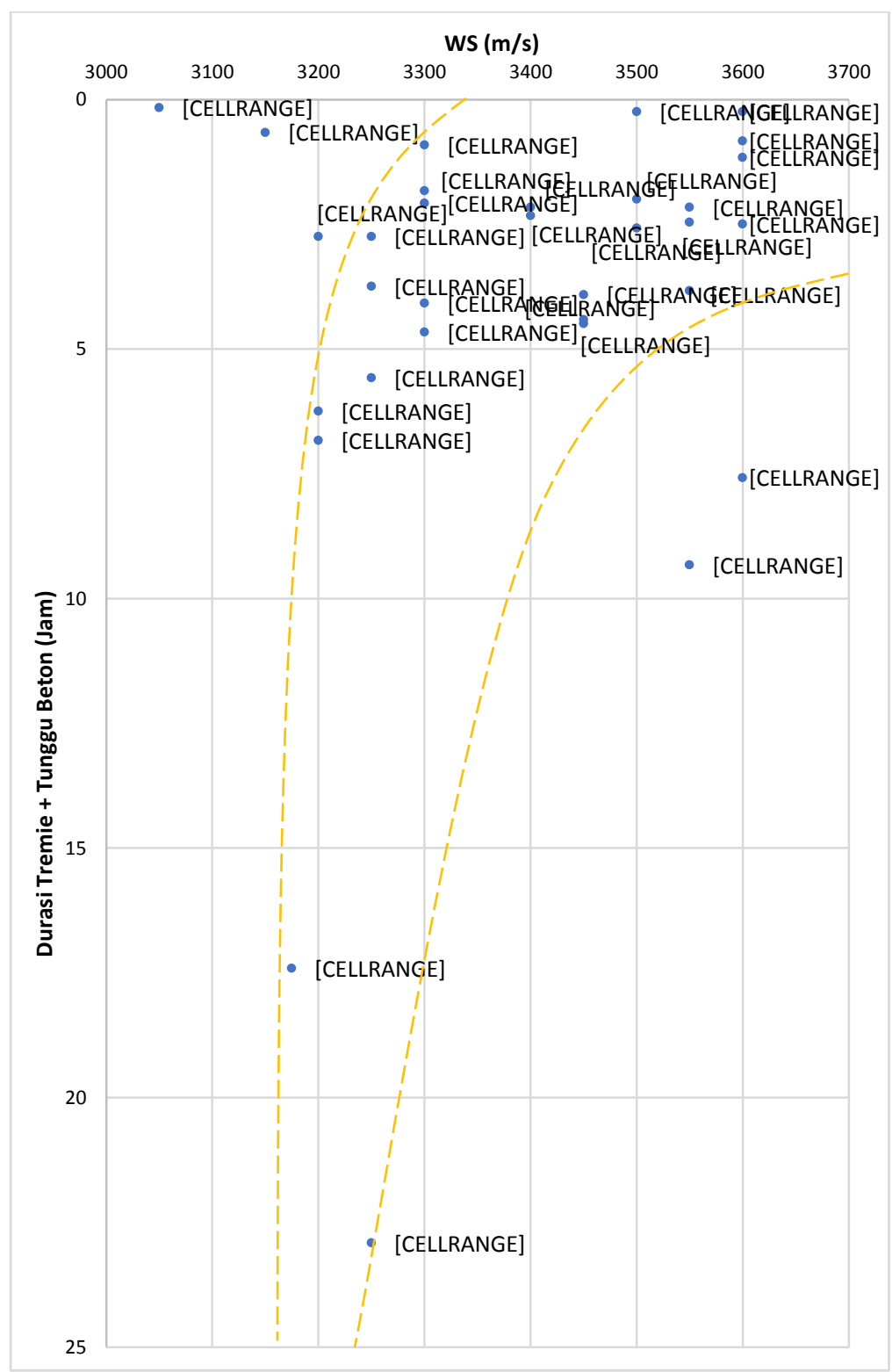

Gambar 3. Grafik Hubungan Cepat Rambat Terhadap Durasi Konstruksi

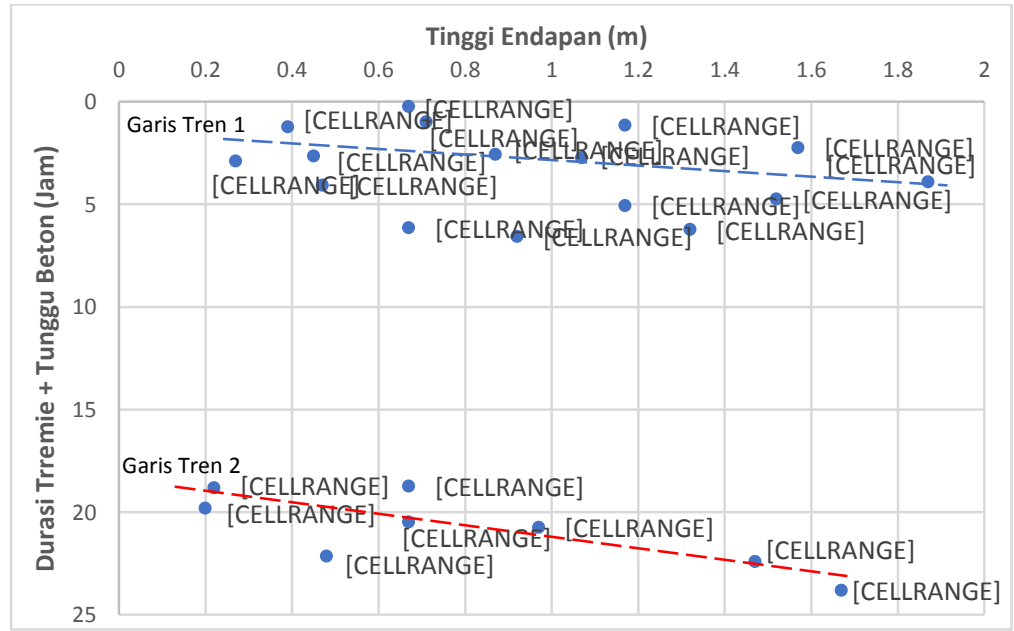

Gambar 4. Grafik Hubungan Tinggi Endapan Terhadap Durasi Konstruksi 
Pada Gambar 5. menunjukkan grafik BTA terhadap durasi kontruksi pada tiang yang mengalami necking. Dari grafik ini didapat bahwa nilai BTA akan semakin kecil jika durasi konstruksi semakin lama.

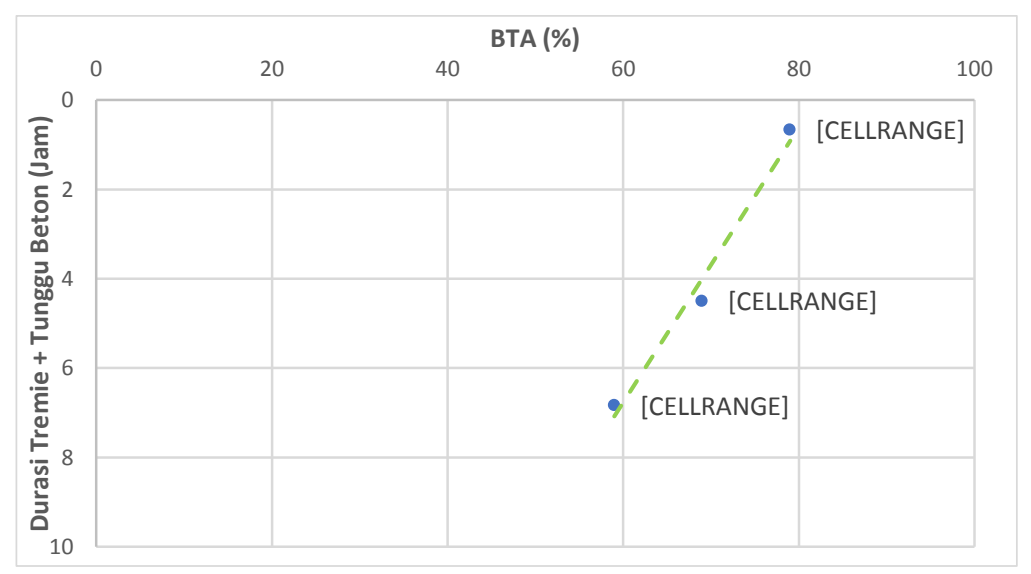

Gambar 5. Grafik Hubungan BTA Terhadap Durasi Konstruksi

\section{Analisis metode pelaksanaan drilled shaft terhadap tanah dispersif}

Pada proyek ini menggunakan casing dengan panjang $8 \mathrm{~m}$ sedangkan diketahui dari penyelidikkan tanah bahwa tanah memiliki muka air tanah yang tinggi dan terdapat tanah dispersif di sepanjang tiang. Tanah yang runtuh diduga merupakan tanah pada kedalaman yang tidak ditahan casing karena tidak menggunakan full casing. Hal ini lah yang menjadi penyebab utama mengapa banyak tiang yang mengalami 3 jenis kecacatan tersebut.

Selain tidak menggunakan full casing panjang tiang yang kurang diduga disebabkan pada saat akhir pengeboran tidak dilakukan pembersihan lubang. Pembersihan harus dilakukan dengan alat pembersih khusus (cleaning bucket) dengan ukuran yang sesuai dengan lubang bor. Untuk memastikan bahwa lubang tersebut sudah bersih, maka sebelum dan sesudah pembersihan harus dilakukan pengukuran kedalaman dasar lubang bor dengan menggunakan pita ukur.

Namun jika terjadi necking di daerah yang ditahan oleh temporary casing. Ada kemungkinan bahwa saat penarikkan casing bersamaan pengecoran, tanah runtuh dan menekan beton yang belum memadat. Ini juga merupakan salah satu kelemahan dari penggunaan temporary casing. Namun jika menggunakan permanent casing merupakan metode yang kurang ekonomis karena casing yang tertanam tidak digunakan lagi. Permanent casing juga mengurangi friksi selimut antara tiang dan tanah sekitar tiang.

Metode casing dapat dipadukan dengan metode basah jika penarikkan full casing memakan waktu. Metode basah ini menggunakan slurry, yaitu campuran air dan bentonite atau polymer biasanya juga digunakan untuk menjaga stabilitas tanah pada muka air tanah yang tinggi. Slurry dapat menahan rembesan air atau tekanan hidrostatis air yang menyebabkan tanah runtuh. Namun diperlukan campuran agar massa jenis slurry lebih besar dibandingkan air tanah namun tidak melebihi massa jenis bubur beton. Agar beton tidak bercampur dengan slurry dan tidak menghasilkan mutu beton yang rendah.

Jika tiang terindikasi mengalami defect (kerusakan) harus dipertimbangkan untuk diterima jika hasil perbaikan memenuhi syarat, atau ditolak dan tiang baru harus bangun. Pertimbangan ini pengaruh oleh besarnya kerusakan dan letak kerusakan. Kerusakan ini mempengaruhi daya dukung yang diberikan oleh tanah maupun kapasitas dari tiang tersebut. Semakin dangkal letak kerusakan tiang berarti semakin kecil daya dukung yang akan diberikan oleh tanah jika tiang tersebut patah.

\section{KESIMPULAN}

Dari hasil analisis pengaruh tanah dispersif terhadap keutuhan dan daya dukung fondasi drilled shaft dengan metode casing, dapat disimpulkan bahwa:

1. Tanah dispersif dapat menyebabkan kerusakan tiang seperti penurunan mutu beton, perpendekkan panjang tiang, dan pengecilan diameter tiang (necking).

2. Meningkatnya durasi konstruksi sekitar lebih dari 6 jam maka akan menyebabkan peningkatan kerusakan tiang. 
3. Dalam melakukan pelaksanaan konstruksi harus mengetahui kedalaman lapisan tanah dispersif sehingga dapat menggunakan casing dengan panjang yang tepat.

4. Pengaruh kerusakan tiang paling besar yaitu sekitar $<50 \%$ terhadap daya dukung fondasi adalah pengurangan panjang tiang akibat endapan tanah dispersif pada dasar tiang. Hal ini dikarenakan fondasi didesain terutama berdasarkan daya dukung ujung.

\section{DAFTAR PUSTAKA}

ASTM D1143-07 Standard Test Methods for Deep Foundations Under Static Axial Compressive Load. American Standard Testing and Material.

Coduto, D.P., W.A. Kitch, and M.R. Yeung (2016). Foundation Design: Principles and Practices (Third Edition). Pomona, California: Pearson.

FHWA-CFL/TD-08-008 Drilled Shaft Axial Capacity Effects Due to Anomalies. U.S. Department of Transportation Federal Highway Administration.

FHWA-NHI-10-016 Drilled Shaft: Construction Procedures and LRFD Design Methods. U.S. Department of Transportation Federal Highway Administration.

Terzaghi, Karl and Ralph B. Peck. (1967). Soil Mechanics in Engineering Practice $2^{\text {nd }}$ Editon. Wiley. 